\title{
Correction to: Is There a Mineral-Induced 'Economic Euphoria'?: Evidence from Latin America
}

\section{Paul Fenton Villar ${ }^{1}$ (D)}

Published online: 20 November 2021

(c) Springer Nature B.V. 2021

\section{Correction to: Journal of Happiness Studies https://doi.org/10.1007/s10902-021-00455-5}

During the typesetting process of the article, the appendices were unfortunately incorrectly labelled as Table 6, Table 7, ... and Table 13. These labels are now corrected as Appendix 1, Appendix 2, ... and Appendix 8.

The original article has been corrected.

Publisher's Note Springer Nature remains neutral with regard to jurisdictional claims in published maps and institutional affiliations.

The original article can be found online at https://doi.org/10.1007/s10902-021-00455-5.

Paul Fenton Villar

p.fenton-villar@uea.ac.uk

1 School of International Development, University of East Anglia, Norwich NR4 7TJ, UK 